\title{
Raúl Prebisch and economic dynamics: cyclical growth and centre-periphery interaction
}

\author{
Esteban Pérez Caldentey and Matias Vernengo
}

ABSTRACT

Prebisch believed that understanding the evolution of capitalist economies over time and in different contexts required a general cycle approach, encompassing all the different areas of economic activity, which he labelled "economic dynamics." This theory, developed between 1945 and 1949, stemmed from a critique of both neoclassical and Keynesian theories, which Prebisch viewed as static representations of capitalism. It was applied first to a closed economy and then to a centre-periphery context. The theory combined the notion that profit is the driving force of economic activity, with a process of forced savings and the idea that the time lag between income circulation (and the resulting demand) and the completion of the production process are the main source of cyclical fluctuations. Prebisch's dynamics theory, which he never completed, influenced his "development manifesto" (Prebisch, 1950). Commission for Latin America and the Caribbean (ECLAC). esteban.perez@cepal.org

Matías Vernengo is associate professor at Bucknell University (Lewisburg, PA), United States of America. m.vernengo@bucknell.edu 


\section{I}

\section{Introduction}

Raúl Prebisch (1901-1986) argued that the cycle is the natural way in which capitalist economies evolve and grow over time. He also asserted that the cycle took a particular form, that of a wave motion. Moreover, he thought that this type of movement characterized all the different facets of economic activity, including production, employment and distribution. Following his departure from the Central Bank of Argentina in 1943, Prebisch set to work developing a general cycle approach that could account for the wave motion in capitalist economies. He termed this approach "economic dynamics."

Prebisch developed his views in two stages. The first stage, from 1943 to 1948 , focused on a critique of the existing body of economic theory at the time. Prebisch maintained that both classical and Keynesian analyses had failed to grasp and incorporate the essential cyclical features of capitalism and, thus, that such analyses were removed from the working reality of free-market economies. Classical economics viewed capitalism through a static framework bounded by the trend towards the full utilization of resources through variations in relative prices and, in particular, in the rate of interest.

According to Prebisch, Keynes's economics suffered from the same flaw. In spite of his statements to the contrary, Keynes was never able to escape the mental habits of the classical mode of thinking. His analysis, particularly in his General Theory of Employment, Interest and Money (1936), also remained anchored in a static conception of capitalism. Keynes replaced the relative price adjustment of classical economics, and more specifically the adjustment of interest rates, with an approach based on income variations (the multiplier) which brought about instantaneous equality between investment and savings.

Prebisch articulated these critical thoughts in part through a series of lectures that took place in Buenos Aires between April 1945 and October 1948 under the title "Political Economy (Economic Dynamics)." The first lectures offered a critique of classical economics and of Keynes's General Theory. These lectures bore the title "The Crisis in Political Economy: Keynes and the Classical Economists." "As part of the development of

1 In 1947, the programme for the Political Economy (Economic Dynamics) course included 11 separate sections. The first four sections his dynamic theory, Prebisch's analyses of Keynes led him to publish his Introducción a Keynes [Introduction to Keynes], which laid out the main ideas of the General Theory (Prebisch, 1947a).

In a second stage, from 1948 until he joined the Office of the Executive Secretary of the Economic Commission for Latin America (ECLA) in 1949, Prebisch began to pull together the main building blocks of an alternative approach that could explain the wave motion in capitalist economies, thus capturing precisely the element missing from classical and Keynesian analyses. Most of the ideas that led Prebisch to his alternative model were developed during a series of lectures delivered at the University of Buenos Aires in 1948 and at the National School of Economics in Mexico City in February and March 1949. ${ }^{2}$ The Buenos Aires lectures were titled "Economic Dynamics" and the Mexico City lectures, "Dynamic Theory of Economics" (with particular application to Latin American economies).

Prebisch's dynamic model consists of a two-class (the working class and the businessmen) economy with two spheres of activity (production and circulation) producing final consumer goods mainly with circulating capital. The model also includes a banking system that adapts passively to demand for credit. The introduction of a time dimension makes the model dynamic.

Time intervenes in the model in the production process, since a period of time must elapse between the start of a given production process and its completion. Time also intervenes in the circulation sphere. The wage bill is entirely spent on final consumer goods, but it returns as income to the businessmen with a lag, only after a certain period of time. Prebisch maintained that the duration of the production and the circulation processes differs: the production process is longer than

focused on the gold standard, Bretton Woods and the value of money and inflation. Sections six to eleven dealt with the theories of the cycle and their empirical verification with a focus on Argentina, including the policies followed by its Central Bank under Prebisch's leadership. See Prebisch, 1947b.

2 The first lecture in Mexico was given on 18 February 1949 and the last on 1 March 1949 (Prebisch, 1993a, vol. 4. pp. 410-489). See footnotes to "Teoría dinámica de la economía (I)" [Dynamic Theory of Economics (I)] (Prebisch, 1993b) and "Introducción al curso de dinámica económica" [Introduction to the Course on Economic Dynamics] (Prebisch, 1948a). See also Prebisch, 1948c. 
the circulation process. It is precisely this disparity in the length of the two processes that generates the wave motion in a capitalist economy, i.e. its dynamics.

Prebisch's dynamic analysis was meant to show that, if the wave motion in capitalist economies is correctly understood, economic forces would never lead to an equilibrium point, but rather to a series of upturns and downturns within which the economy was growing. This was his understanding of cyclical growth. He eventually extended his dynamic analysis to include the relationship between the centre and the periphery.

In March 1949, at the end of his lectures on economic dynamics, Prebisch was convinced, that his theory was general rather than specific to a particular setting and circumstance. However, probably due to time constraints and pressing commitments, he never fully developed his dynamic theory. In 1949 he joined the then Economic Commission for Latin America (ECLA), first as a consultant and then, two years later, as its Executive Secretary. By then, his interest had turned to the problem of industrialization in Latin America, as attested by the publication of The Economic Development of Latin America and its Principal Problems (Prebisch, 1950), his "development manifesto", and "Crecimiento, desequilibrio y disparidades: interpretación del proceso de desarrollo económico" [Growth, disequilibrium and disparities: interpretation of the process of economic development] (Prebisch, 1951b), which nevertheless were clearly influenced by his cycle and dynamic analyses.

This paper provides a systematic and critical exposition and analysis of Prebisch's economic dynamics. It is divided into eight sections. Following this Introduction, section II discusses his critique of the neoclassical theory and Keynes's General Theory as static representations of capitalist development. Sections III to VI lay out the building blocks of Prebisch's dynamic theory and its development. Section VII follows Prebisch's application of his dynamic theory to the centre and the periphery and argues that, according to Prebisch himself, his dynamic theory was a general theory rather than a specific one, and thus it was capable of incorporating different assumptions and varying parameters and situations without altering its core analysis and foundations. The conclusions are found in section VIII.

\section{II}

\section{Neoclassical theory and Keynes's General Theory: two static representations of capitalism}

Prebisch believed that the growth process in capitalist economies was eminently cyclical. As he put it: "The cycle has historically been, and continues to be, the typical manner of growth for capitalism. Economic activity... expands and contracts continually in an interrupted succession of phases of growth in income, employment and production, which are followed by phases of decline, with a consequent decrease in production and employment" (Prebisch, 1948a). ${ }^{3}$ His understanding of capitalism is typical of many authors of this period. For Prebisch, the cyclical reality of capitalist growth undermines the whole notion of equilibrium, understood in the Smithian sense as a centre of gravity, and all the more so when considered in terms of the neoclassical notion of allocative efficiency. As Prebisch argued: "There is no resting point: an upswing is followed by a

\footnotetext{
${ }^{3}$ See also Prebisch, 2003a.
}

downswing, only to be followed by another upswing... In this movement there is no equilibrium point; this movement is a continual succession of disequilibria" (Prebisch, 1948a). This idea applies to both static and dynamic equilibria.

Prebisch came to be highly critical of the prevailing economic theory because it was anchored in equilibrium analysis and was, thus, divorced from capitalist reality. In his view, both neoclassical and Keynesian theories suffered from the same flaw.

His critique of the neoclassical theory focuses on the marginal productivity theory. Prebisch argued that the marginal productivity theory implied that the evolution of a market economy could only be characterized by a regular line of advance and, in more modern terms, that it was only compatible with steady-state growth, a concept and expression that became a fundamental part of the mainstream toolkit only a decade later. Prebisch correctly understood that steady-state growth is determined by 
the population growth rate and technical innovation. ${ }^{4}$ For Prebisch, the notion of steady-state growth was antithetical to the very nature of capitalist evolution.

Prebisch illustrates his point with an implicit model comprising an investment and consumer goods sector. The application of the marginal productivity theory to this type of model meant that if output expands in a steady-state manner, both investment and consumption also have to expand at a steady- state growth rate and, thus, maintain a given ratio over time. In other words, the marginal productivity theory presupposes a balanced process of growth, implying that the competitive conditions ensure that the output of capital maintains a given relationship relative to consumer goods, which is determined by the population growth rate, technical innovation and preferences. Any divergence from that investment/consumption ratio is eliminated through changes in resources brought about by the difference between the marginal product of capital and the rate of interest. If the ratio of investment to consumer goods exceeds (falls short of) the ratio compatible with balance growth, the marginal product of capital would be below (above) the rate of interest, causing a shift of resources from the production of capital (consumption) to consumer (investment) goods. This would lead the marginal product of capital to increase (decline) until it reached equality with the interest rate. As explained by Prebisch:

"The logical relationship between capital and consumer goods industries derives from the population growth rate, technical innovation and the savings preferences of the community. Thus, if for any reason greater capacity were to be created in a given industry than was justified by the level of consumption, since investment is simply an advance of expected consumption, if there is excess capacity, the productivity of the increase in capital brought about by this excess would be lower than the interest rate, and this would eliminate the excess. Accordingly, excess capacity for the production of articles or capital goods cannot be conceived of in either specific cases or specific sectors of the economy..." (Prebisch, 1948f).

In this view, the interest rate acts as a centre of gravity for the marginal product of capital and is the central coordinating mechanism of economic activity. Prebisch viewed the interest rate, as defined by the neoclassical authors, as an artifice, albeit a useful artifice, for it allowed neoclassical theory to remain within the

\footnotetext{
${ }^{4}$ See Prebisch, $1948 f$.
}

confines of static equilibrium theory even when analysing a capitalist production-type economy. For Prebisch, the process of production requires the passage of time or a period of time during which savings must be generated and transformed into capital. As he puts it:

“... a more or less lengthy period of time elapses between the initiation of operations and the termination of the final product to be made available to the consumer. Meanwhile the factors of production involved in this intermediate production phase that creates —as time goes by — the final product, need to consume and if they do not save, i.e. if they stop consuming - even to a small degree - other factors within the community must forego consumption so that they can consume. To forego consumption is to save and transfer what is not consumed to those working in intermediate production. It is to invest these savings in intermediate production, i.e. to invest these savings in capital formation, since intermediate production - all that is being transformed into final products, a more or less lengthy process- is capital" (Prebisch, 1948b, p. 272).

The classical theory allows the process of transforming savings into capital to be perfectly synchronized by changes in the interest rate. The interest rate is the "theoretical artifice", as Prebisch termed it, for the required synchronicity. According to Prebisch, neoclassical theory holds that it is "... not possible to invest without having an equivalent and simultaneous amount of savings" (Prebisch, 1948b). In other words, the interest rate regulates savings in such a way as to make the act of saving and that of investing a simultaneous occurrence.

After laying out his critique of neoclassical theory, Prebisch turns the focus of his analysis to John Maynard Keynes. He argues that Keynes was never able to free himself completely from the fetters of the classical theory and remained attached to the neoclassical notion of equilibrium. Having disparaged the neoclassical theory of interest rates, which he criticized profusely in his General Theory, Keynes used an alternative artifice as a means of disregarding time, asserting that the multiplier and the associated changes in income would generate the required savings to "finance" investments. Prebisch interprets the multiplier as an "instantaneous multiplier". As he puts it:

"The revolutionary aspect of Keynes, from a theoretical point of view, is his famous theory of the multiplier, which is another theory of economic equilibrium very similar in its structure to the old quantity theory of money. Such is the strength of that mental habit, from which Keynes would never 
emancipate himself. He thus followed the classical economists where he should have followed them the least: in the search for laws of equilibrium, which is, in my opinion, the greatest obstacle to the progress of political economy from a theoretical point of view. If these obstacles are not forcefully removed, we will continue to formulate constructs that are disconnected from reality" (Prebisch, 1948a). He went on to explain:

"That is, given an increase in investment, income will grow in the amount required to produce an increase in savings in the community equivalent to the increment in investment. It is clear that such reasoning could only come from a theoretician who disregards time. Why? Because time is indispensable in order for an increment in investment to trigger an increment in income, so ultimately, Keynesian thinking is to say: in order to invest today, we will use savings that will be made in the future (...). Such reasoning is possible only if the future is confounded with the present and the time factor is eliminated completely from the process. This is one of the great logical inconsistencies that invalidate Keynesian theory"5 (Prebisch, 1948b, p. 277).

5 Schumpeter (1946) put forward a similar critique of Keynes's General Theory.

\section{III}

\section{Main elements of Prebisch's dynamic theory}

Having argued that the static constructs of the neoclassicists and Keynes are not relevant to the understanding of capitalism, Prebisch emphasizes the need to formulate a dynamic theory capturing the time dimension and the wave motion in capitalism, with the understanding that this theory would encompass the entire spectrum of economic activity. In his own words:

"I am increasingly convinced that the cycle is the way in which a capitalist economy grows. A capitalist economy expands only in a wave motion, it has moved only in that manner and any perturbation of the economy as a whole gives that motion a wave form. Therefore, if the cycle is the way in which the economy grows and moves, and if the economy moves incessantly in this manner, it would seem that all the phenomena occurring in the economy as a whole — not just those relating to production and employment, but also those relating to distribution - should be included in a general dynamic theory" (Prebisch, 1993b, p. 414).

A dynamic theory should explain not only the rationale for the alternating phases of prosperity and depression that characterize capitalist economies, but also the processes of production and distribution. ${ }^{6}$

${ }^{6}$ As Prebisch notes, The theory of economic dynamics purports to explain this [cyclical] way in which phenomena occur and to identify
Prebisch's dynamic analysis is presented in terms of a model comprising two social classes, businessmen and workers, with two spheres of activity, production and circulation. He assumes, furthermore, that the banking system reacts passively to demand for credit, that the economy produces final consumer goods and that workers' wages are spent entirely on final consumption such that businesses recoup the money spent on production.

The time variable enters into the production and circulation processes in a fundamental way. A production process does not take place instantaneously; it takes some time. Between the start of any production process and its end result (the output of finished goods), a value is added to the process at every interval, so that the whole production process consists in a sum of values added. Alongside the process of creating value added

their uniformities, in order to formulate the principles or laws that govern that movement. Likewise, he affirms that the dynamic theory also plays a fundamental role in the analysis of three of the main characteristics of a free-market economy: the instabilityof the economic system, the inequality in income distribution and persistent unemployment. In this sense, Prebisch shares some of Keynes's views on investment and on the flaws of capitalism, namely "its failure to provide full employment and its arbitrary and inequitable distribution of wealth and incomes" (Keynes, 1943). See Prebisch, 1948b; 1948e; 1948f, and 1947a. Prebisch adds instability to that list (Prebisch 1948b and 1948e). 
(a production process) there is a process of income generation. Means of production have to be purchased, and participants in the production process earn an income for their contribution.

Some wages and profits are distributed before the end of the production process. The time span between the period during which earnings are distributed (circulation sphere) and the period required to complete the production process (production sphere) creates a disparity between aggregate demand and aggregate supply and is the source of profits and of the cycle. In other words, the fact that the monetary and real spheres operate in different time periods explains why economies evolve through a series of disequilibrium positions rather than tending towards an equilibrium position (Prebisch, 1948a).
The upward phase of the cycle is characterized by an excess of income over value added, i.e. an excess of aggregate demand over aggregate supply. This in turn translates into higher expenditure, prices, profits and investment. The flow of investment expenditure then eventually returns to the businessmen in the form of profits.

In the downward phase of the cycle, as aggregate supply exceeds aggregate demand, prices and profits decline, leading to a process of disinvestment. As upward and downward phases alternate, Prebisch maintained that "... a capitalist economy is characterized by a continuous process of investment and disinvestment, with this peculiarity: in general, in the disinvestment process not everything that has been invested is disinvested; otherwise, there would be no economic growth" (Prebisch, 1993b, p. 425).

\section{IV}

\section{Schematic representation of Prebisch's analysis}

Prebisch expands his analysis of dynamics through a graphic representation consisting of a plane divided into two right triangles of equal area. The first triangle (ADF) represents production in process. The second triangle (FDK) represents finished production. Prebisch considers only circulating capital at this stage. The two-triangle plane is meant to capture three dimensions of the production process: the time elapsed during this process; real output, including both production in process and final production (the quantity of production); and the money income paid to the factors involved in the production process. Prebisch assumes that there are nine production processes and that each one takes nine months to produce one unit of final output.

Further, he assumes that wages are only paid while production is in process, that such wages are spent on final consumer goods and that there are no profits at this stage. Businesses recapture the income they pay to workers (their wage bill) through the sale of final commodities. Prebisch assumes, furthermore, that business earnings are, in turn, reinvested in the production process.

The base of the ADF triangle (AD) represents the stages of a production process, which Prebisch divides into nine equal time periods (or months). The hypotenuse of the triangle $(\mathrm{AF})$ represents both the incomes paid for production in process and the sequential start of each of the series (or nine stages) of the nine production processes. The hypotenuse of the FDK triangle (DK) represents the incomes paid for the finished goods (see figure 1).

At the end of the first nine months, the first production process (denoted by $\mathrm{ABCD}$ in the first (AFD) triangle) produces one unit of finished goods (denoted by CDH in the second (FDK) triangle), which is equivalent to ABK. These goods are sold and the proceeds are then reinvested and added to the production in process (ADF). At this point, businesses begin the second production process, which will take nine months. After this is completed, the finished output appears as ICHJ in the second (FDK) triangle. ICHJ is equivalent to the sum of the reinvested proceeds $(\mathrm{CDH})$, plus the addition to final output resulting from the second production process, but without taking into account the proceeds reinvested from the final output of the first production process (ICHK). Thereafter, the process is repeated until the nine production processes are completed, with each one contributing the same volume in process to the final output. At the end of the entire process, total income paid will be equal to total income received for final output ( $\mathrm{AF}=\mathrm{DK}$ or $\alpha=\beta)$.

This steady-state system (comprising workers who receive wages that are then paid to businesses 
for the purchase of final commodities and businesses which reinvest those proceeds) can only expand if the incomes paid for production in process exceed the incomes received by businesses for the sale of final output. This is shown by the displacement of AF to AL, which leads to an increase of incomes paid to factors for production in process over and above final output (DK) $\left(\alpha=\beta\right.$ and $\left.\alpha_{1}>\beta\right)$.

Figure I

Prebisch's dynamics as a process of circulating capital

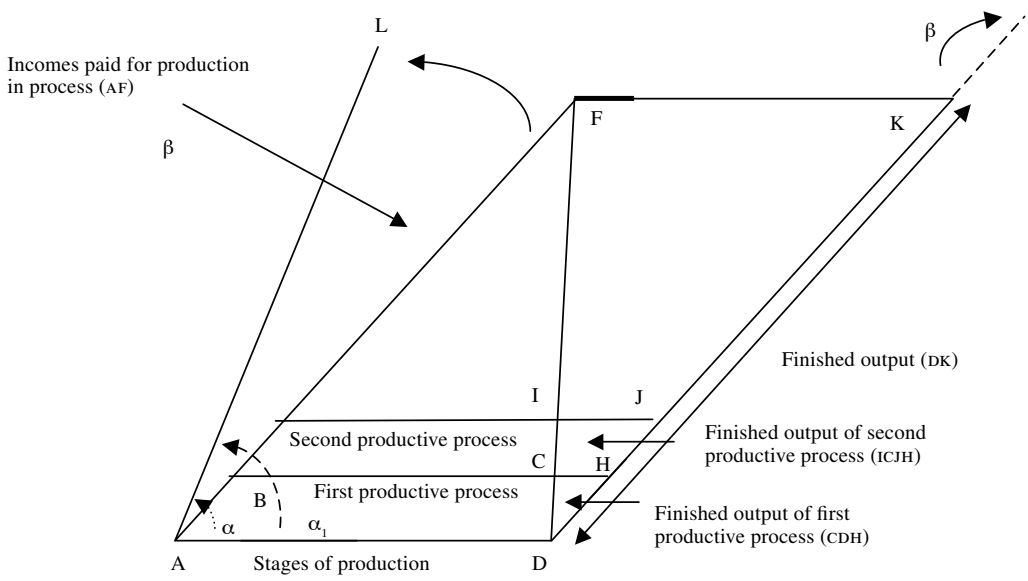

Source: Prepared by the authors, on the basis of R. Prebisch, "Teoría dinámica de la economía (II)", Raúl Prebisch: Obras, 1919-1948, vol. 4, Buenos Aires, Raúl Prebisch Foundation, 1993.

\section{V}

\section{Profits and forced savings}

At a later stage, Prebisch proceeds to introduce profits into his analysis. In fact, they constitute the pivot on which Prebisch's dynamic theory is built. Profits derive from forced savings.

As Prebisch puts it:

"... the largest portion of investment in fixed capital is covered indirectly by an increase in money, not by recourse to the market in accordance with the laws of supply and demand in classical economics...How does the increase in money work?... the increase in money put into circulation by people to pay for investment causes prices to rise... The increase in prices implies a fall in real wages... in order to compel those who pay the highest prices to save, transferring these savings to the businessmen in the form of consumer goods; the businessmen in turn transfer the savings to those engaged in capital formation... most savings are not the result of a mechanism of incentives and preferences, but of a mechanism of compulsion. Saving is compelled when there is not enough spontaneous saving" (Prebisch, 1948c).

Prebisch firmly believes that savings precede investment, and that the undertaking of investment necessarily required a prior act of savings. As he argues (Prebisch, 1948c): "I am convinced that foregoing consumption is essential in order to capitalize investments. In this point I agree with the reasons espoused by the classical school and I disagree with Keynes."

Nonetheless, Prebisch views the notion of forced savings as incompatible with the neoclassical orthodox idea of savings, which conceives it as the result of individual preferences. He expresses it as follows: "A large portion of investment has historically been undertaken, and continues to be undertaken, by a mechanism very different from supply and demand for savings, and a 
large portion of the savings that are invested is not the result of what the community spontaneously decides on the basis of its inclinations and tastes and the interest rate" (Prebisch, 1948b).

According to Prebisch, profits result from an excess of demand over supply and materialize from the beginning to the end of the production process. The profit transmission mechanism encompasses the spectrum of different businesses involved from the beginning to the end of the production process: raw material producers, industrialists, wholesalers and retailers. Prebisch assumes that prices for retailers are fixed, while prices for wholesalers, manufacturers and raw material producers are flexible. In addition, retailers aim for a certain normal level of inventory.

Faced with an increase in demand for final products, retailers reduce their inventories below their normal level, which leads to increased demand for products from wholesalers and to higher prices and profits. Wholesalers, in response to the higher prices and profits, then expand their operations, and their demand for products from industrialists increases. The same mechanism leads to increased demand from industrialists for products from raw material producers. The rise in demand and the higher prices and profits are thus transmitted throughout the production and distribution process. At every stage, the rise in demand, prices and profits is accompanied by a concomitant increase in the wage bill (Prebisch, 1993c and 1993d). This process yields a rise in wages and profits, which are then incorporated into the prices charged by all types of businesses to each other and to final consumers. Hence, the primary products sold to industrialists, the wholesale products sold to retailers and the final products sold to consumers will have incorporated the new profit level, itself the result of an imbalance between aggregate supply and aggregate demand.

Prebisch thought that once a higher level of profits was incorporated into the whole production process, those profits could not be squeezed, nor could they act as the adjustment mechanism in case of a decline in demand. Thus, just as profits and the anticipation of profits act as the trigger to boost production and incomes, they are also an important source of rigidity in the system which prevents it from operating in the way the classical economists theorized. As Prebisch puts it:

"... profits that have accumulated during the production process are irreversible, and therefore even if the conjectures made by businesses regarding future demand, which have given rise to this advance crystallization of profits during the production process, fail to materialize, the product that is offered in the market already incorporates those profits in such a way that they cannot be reduced, because they have been paid at the various stages... Thus, as a result of the crystallization of profits, the levels of supply in the production process acquire a rigidity that will trigger a cyclical contraction when demand, after the point of convergence, is insufficient to absorb supply" (Prebisch, 1993c).

In accordance with this reasoning, the level of profits per unit produced for each category of business, with the exception of raw material producers, is determined by the profit margin between the different stages in the production process, which in turn depends on the degree of competition (or as Prebisch (1993d) expresses it: "competition and mobility").

On the other hand, the level of profits is determined by the time elapsed between when the desired level of demand is reached and when a product is brought to the market. For commodity producers, the level of profits depends only on the duration of the interval between the purchase of a product and its sale. In the case of retailers and wholesalers, the time elapsed between purchase and sale involves the different transactions that are undertaken in the circulation sphere of the production process not in the production sphere per se as in the case of manufacturers (industrialists) and raw material producers.

More specifically, the level of profits accruing to retailers $\left(\pi_{R T}\right)$ will be determined by a profit margin over and above the profit level of wholesalers $\left(\pi_{W T}\right)$ and the time elapsed between purchase of products from wholesalers and sales to the final consumer. In turn, the level of profits accruing to wholesalers $\left(\pi_{W T}\right)$ will be determined by a profit margin over and above the profit level of industrialists $\left(\pi_{I}\right)$ and by the time span between purchase and sale. The level of profits of industrialists $\left(\pi_{I}\right)$ will be determined by a profit margin over and above the profit level of raw material producers and by the duration of the manufacturing process. In the case of raw material producers, profits are determined only by the time elapsed between planning and extraction of raw materials and their sale to the manufacturer. Formally,

$$
\begin{gathered}
\pi_{R T}=\mu_{1} \pi_{W T}+\theta_{R T} \\
\pi_{W T}=\mu_{2} \pi_{I}+\theta_{W T} \\
\pi_{I}=\mu_{3} \pi_{R M}+\theta_{I} \\
\pi_{R M}=\theta_{R M}
\end{gathered}
$$


where $\mu_{i}$ and $\theta_{i}$ represent the respective profit margins and duration of the production process for each business or producer category (retailers, wholesalers, industrialists and raw material producers). Successive substitution means that the level of profits in the retail sector depends on the different mark-ups applied at each stage of production and distribution weighted by the time elapsed between purchase and sale of raw materials, manufactured products and wholesale goods and by the time required to bring raw materials to the market for sale. That is:

$$
\pi_{R T}=\mu_{1}\left[\mu_{2} \mu_{3} \theta_{R M}+\mu_{2} \theta_{I}+\theta_{W T}\right]_{+} \theta_{R T}
$$

Under conditions of perfect competition, $\mu_{i}=0$ and the existence of profits for retailers is only explained by $\theta_{R T}$. In the opposite case, $\mu_{i}=1$, profits arise out of the time elapsed for all production and distribution processes. As equation (2) illustrates, the retailer (under the assumption that he will realize his planned sales) obtains his own profits and also recaptures all the other profits made and paid at each stage of the production process. Even prior to the final sale of a product by the retailer, profits are earned and incorporated into the price charged by every business that intervenes in the process. As retailers face fixed prices, an increase in demand for final consumer goods will reduce the retailer's inventory. As explained above, this will trigger an increase in demand from retailers for wholesale products, from wholesalers for manufactured products, and from manufacturers for raw materials. As these businesses operate in flex-price markets, the rise in demand will result in a price increase and an expansion of profits throughout the production chain. Higher profits (and profit expectations) will result in increased demand for investment, labour and all the types of goods used in the process from raw material producers to wholesalers. This greater demand for labour and goods will translate into higher wages and goods prices.

Prebisch explains this in the following way:

"We already know that profits have built up during the different stages of the production process. When the retailer acquires products from the wholesaler, the former pays the latter all the earlier profits; and when these articles are sold, the retailer recovers all of those profits... and also obtains his own profit... In other words, the consumer pays the retailer's profits and also returns all of the profits realized earlier in the production process. Meanwhile, in the upward phase, at the same time that the retailer recovers the profits that he had previously paid out, he is paying greater profits; there is thus an increase in profits. This increase will give rise immediately to an adjustment at all stages because as the production process proceeds from business to business each receives a part of the increment [in profits]" (Prebisch, 1993d, p. 443).

\section{VI}

\section{General aspects of Prebisch's dynamic theory}

Prebisch's overall view of dynamics can be summarized with the aid of one of the figures found in his "Teoría dinámica de la economía (I)" [Dynamic Theory of Economics (I)] (Prebisch, 1993b) (see figure 2). The figure shows the demand and supply sides of the production process and their interaction in the upward and downward phases of the economic cycle. Demand is determined by earned and spent income. Supply is determined by production output (whether of production in process or final production). Figure 2 shows three parabolic curves: incomes paid by producers of final goods to factors of production; finished production (output of finished goods) and demand (D) for final goods. The three curves rise and evolve at different speeds, illustrating the time structure of production.

On the demand (income) side, the incomes paid to the means of production $\left(I_{p f p}\right)$ give rise to the demand curve for final goods (D), which in turn translates into income that returns to businesses $\left(I_{r e}\right)$. In other words, demand (D) is equivalent to income returning to businesses $\left(I_{r e}\right)$. During the production process, producers pay wages and profits for production, which return to them as income (i.e. profits) in a circular flow. On the supply side, production in process $\left(P_{p}\right)$ gives rise to the finished production $\left(P_{T}\right)$ curve and, by construction, $P_{p}$ is equivalent to the incomes paid by producers of final goods to the factors of production $\left(I_{p f p}\right)$. 
FIGURE 2

A schematic representation of Prebisch's views on dynamics (1949)

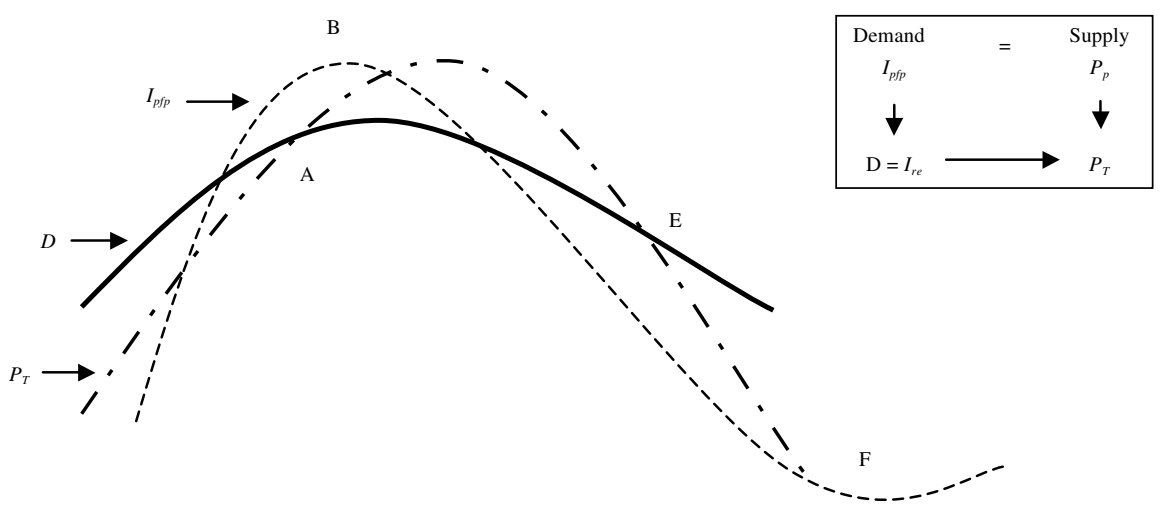

Source: Prepared by the authors, on the basis of R. Prebisch, "Teoría dinámica de la economía (I)”, Raúl Prebisch: Obras, 1919-1948, vol. 4, Buenos Aires, Raúl Prebisch Foundation, 1993.

According to figure 2, starting with the upward phase of the cycle, incomes are paid to the means of production $\left(I_{p f p}\right)$ and thus production in process $\left(P_{p}\right)$ tends initially to outpace finished production $\left(P_{T}\right)$, owing to the lag in the production structure up to point A. As a result, demand (D) during this phase is higher than finished production or supply. At point A, demand (D) and finished production output $\left(P_{T}\right)$ intersect. Yet, according to Prebisch, A is not an equilibrium point. This is due to the fact that producers are still undertaking production in process $\left(P_{p}\right)$ and, as a result, even at the point of convergence of the two curves (A), finished production $\left(P_{T}\right)$ is increasing at a faster rate than demand (D) (i.e. the slope of $P_{T}$ at A is steeper than that of D). Finished production surpasses D and continues to expand even after demand has begun its decline.

The end result is the accumulation of inventories by businesses and, thus, a reduction in their plans for production in process. This is illustrated by the decline in the slope of $I_{p f p}$ and thus of $P_{p}$. Its point of inflection at $\mathrm{B}$ is the beginning of the downward phase of the cycle. As $I_{p f p}$ slows down, $P_{p}$ and D follow suit.

The decline in D, $I_{p f p}$ and $P_{T}$ continues until the continual depletion of inventories leads again to a point of convergence (E) between demand for final goods (D) and finished output $\left(P_{T}\right)$. Again $\mathrm{E}$ is not an equilibrium point for demand (D), which declines at a slower pace than finished production $\left(P_{T}\right)$. The depletion of inventories will slowly lead businessmen to renew orders for their production process, putting a break on the decline in $P_{p}$ and $I_{p f p}$ and on demand. Eventually, $P_{p}$ will begin to turn around (point F) and will pull $I_{p f p}$ and thus D towards a new upswing of the cycle. ${ }^{7}$

Prebisch's schematic representation illustrates, once again, that the hallmark of the evolution of a capitalist economy is not a convergence towards equilibrium, but recurrent states of disequilibrium. Disequilibrium is continuous, and a situation in which supply exceeds demand leads to one in which demand exceeds supply (Prebisch, 1993b). In addition, there is nothing to guarantee that the fluctuations occur around an optimal level of utilization of the means of production. As relevant and original as Prebisch's analysis of cyclical dynamics was, it is important to note that his extension of capitalist dynamics to deal with the interaction between centre and periphery was unique.

\footnotetext{
${ }^{7}$ In Prebisch's diagram (Prebisch, 1993b, p. 419) finished production $\left(P_{T}\right)$ and production in process $\left(P_{p}=I_{p f p}\right)$ have a similar slope in their decline, but $\mathrm{D}$ has a shallower slope. We believe that this is a slip on Prebisch's part. The depletion of inventories (which is considered production in process) will lead businessmen to expand orders for inputs needed for production in process before final production recovers. Moreover, since the demand (D) curve is derived from the production-in-process curve $\left(P_{p}\right)$ and $\mathrm{D}$ declines at a slower rate than finished production $\left(P_{T}\right)$, so must production in process $\left(P_{p}\right)$. Hence, in figure 2 above, $P_{p}$ declines at a slower rate than $P_{T}$.
} 


\section{VII}

\section{From the closed economy to centre-periphery dynamics}

Prebisch uses the previous framework to analyse the relationship between centre and periphery. He had made extensive use of this analytical dichotomy when, during his earlier analysis of the Argentine economy, he realized that the cycle was part of a global process comprising a cyclical centre and a periphery. ${ }^{8}$

The centre-periphery dynamic theory assumes that the periphery is wholly specialized in the production of raw materials, which are exported to the centre in exchange for manufactures. Profits in the final, retail and wholesale sectors are earned and spent in the centre. Profits from the production of raw materials are realized in the periphery and spent in the centre (i.e. transferred to the centre). As a result, businesses in the centre face demand originating both in the centre and in the periphery. In addition, it is assumed that the centre issues the reserve currency, which constitutes the only currency in the periphery. In other words, the periphery is "dollarized," which might be an extreme assumption, but it reflects the fact that peripheral countries' imports must be paid for in the key currency of a central country. Insofar as the periphery does not have policy autonomy, it plays a passive role and constitutes the space for the circulation of incomes sent from the centre (Prebisch, 1993h). According to Prebisch, the assumption of passivity on the part of the periphery is a realistic one.

Prebisch applies his dynamic analysis for a closed economy to the centre and to the periphery, according to which in the upward phase of the cycle demand tends to outstrip supply because of the difference between the time it takes for incomes to return to businesses (as demand) and the time it takes for output to be finished (supply). This difference triggers an increase of both prices and profits, which in turn justifies additional production commitments.

The application of this framework to a centreperiphery model implies that the undertaking of the production process by the centre necessarily results in positive net demand (an injection) in the centre. Hence, the

8 See Prebisch, 2003c and 1993b, and Pérez Caldentey and Vernengo, 2011. centre experiences excess demand. However, at the same time the centre also experiences leakages equivalent to the value of imports of raw materials from the periphery. This constitutes the income flow paid to businesses and workers in the periphery for the production and export of raw materials sold to the centre. In turn, businesses and workers in the periphery purchase the final goods produced in the centre. Hence the flow of income spent by businesses from the centre in the periphery returns to the centre.

On the one hand, Prebisch postulates that, as in his previous analysis, the time period over which incomes return to businesses is shorter than the time period required to bring the finished products to the market. On the other, it takes longer for incomes to return from the periphery to the centre (demand from the periphery) than for final production in the centre to be brought to the market and sold (in the centre) (Prebisch, 1993f). As a result, at the same time that there is excess demand originating in the centre, there is insufficient demand for final goods in the periphery.

The interplay between the forces and factors determining the excess demand in the centre and the insufficiency of demand in the periphery constitutes the core of Prebisch's dynamics as applied to the centreperiphery dichotomy. At the beginning of an ascendant phase, demand exceeds supply, leading to an increase in prices and profits. Concomitantly, part of the increased income leaks out to the periphery, reigning in the pressure on net aggregate demand. The greater the leakage coefficient is, the smaller the excess net demand will be and, hence, the smaller the profit and the incentives for continued expansion in the centre.

Prebisch contends that the net excess demand will wane over time owing to an increase in the income elasticity of imports for products from the periphery demanded by the centre. The flow of profits (from the centre to the periphery and back) acts as the equilibrating force between demand and supply in the centre. As he puts it:

"...there is an excess of net demand over supply in the cyclical centre, which has the effect of diminishing the inventories of final businessmen, causing a rise in demand among businessmen in order 
to increase production, which leads to an increase in profits, which, under the hypothesis that we are considering, go mostly to the periphery. That is, as long as the point of convergence is not reached, there will be a continuous depletion of inventories, a continuous rise in demand among businessmen, a continuous expansion of profits and a displacement of profits towards the periphery. Profits continue to be displaced in greater and greater measure to the periphery until their amount creates an insufficiency equal to the excess. This is the spontaneous interplay of the system" (Prebisch, 1993f).

This mechanism is reinforced by the assumption that businesses need more time to recoup their earnings from the periphery than to bring their final production to the market and sell it. Precisely for this reason, Prebisch argues that the point of convergence or equilibrium between the excess demand in the centre and the insufficiency of demand in the periphery would be very hard to reach, especially when - as he assumed in his model — the leakage coefficient in the centre is significantly greater than that of the periphery. He provides a specific example in which the leakage coefficient has a value of 0.50 and 0.20 , respectively, for the centre and the periphery (Prebisch, 1993g): "The leakage coefficient, that is, the one that gives us the recoup of earnings, is, according to what we already explained, much higher in the overall income generated in the centre than in the overall income generated in the periphery."

Prebisch further assumes that incomes in the centre would increase by a constant 100 units, whereas in the periphery incomes would rise by 20 units (see figure 3 ). The result is a widening gap between the amount that the centre spends in the periphery and the amount that the periphery spends in the centre, denoted by the distance between the dotted line and solid black line (between points $\mathrm{A}$ and $\mathrm{B}$ ). The dotted line at the top shows the evolution of leakages for the centre with successive increases of 100 units in income and an import coefficient of 0.50 . The solid black line at the bottom plots leakages for the periphery under the assumption of successive increases of 20 units in income and an import coefficient of 0.20. But even if incomes in both the centre and the periphery expanded by the same amount, say 100 units, the gap would still increase (albeit to a lesser extent). In figure 3 , this is shown by the difference between the dotted line at the top and the two lines below it, which plot leakages for the periphery under the assumption of successive increases of 100 and 200 units in income, with an import coefficient of 0.20 for both.

FIGURE 3

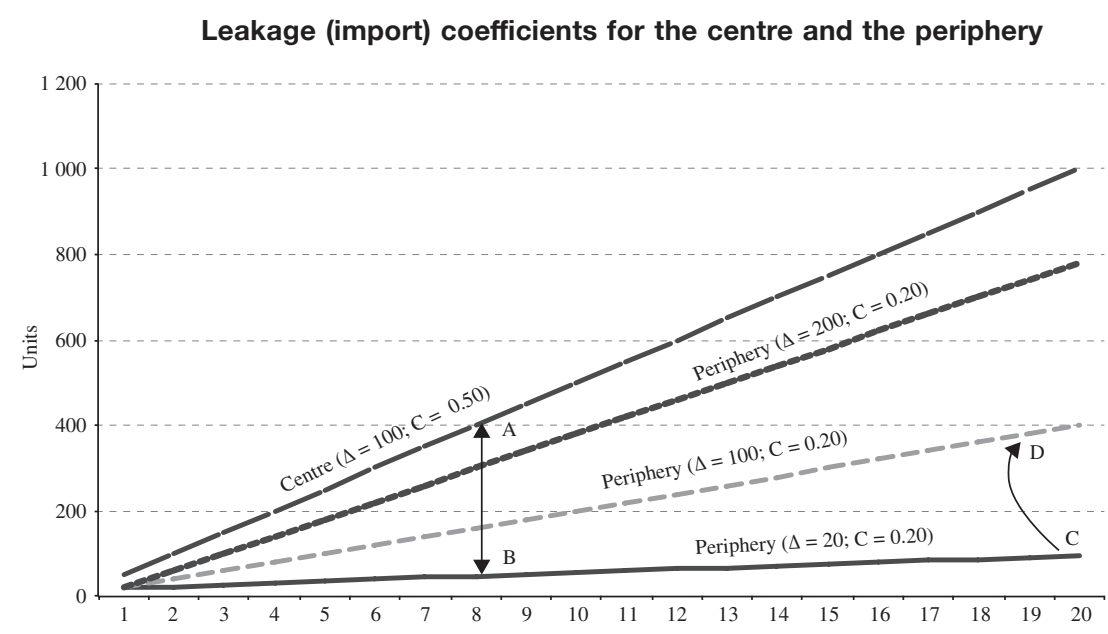

Source: Prepared by the authors, on the basis of R. Prebisch, "Teoría dinámica de la economía (VI)", Raúl Prebisch: Obras, 1919-1948, vol. 4, Buenos Aires, Raúl Prebisch Foundation, 1993.

The fact that Prebisch assumes, at least until his seventh lecture on economic dynamics (Prebisch, 1993h), that the import coefficient is larger in the centre than in the periphery seems a stark contradiction to his thinking.
A key tenet of Prebisch's work, and of the structuralist school, is that the import elasticity of income in the periphery is higher than in the centre (see, for example, Prebisch, 1950). From the point of view adopted in this 
study, this contradiction can be explained by means of two hypotheses.

First, Prebisch was aware that, since around 1926, developing countries had been experiencing declining terms of trade and that this was a relative price effect. But he did not specifically address the differences in income effects between centre and periphery, even when he addressed the issue of trade between a developed and a developing country in a 1948 lecture entitled "El esquema clásico del comercio internacional y el oro en la realidad" [The Classical Scheme of International Trade and Gold in Reality], as part of his course on economic dynamics. ${ }^{9}$ Perhaps Prebisch began to be explicitly aware of the importance of income effects in the external sector around the time he was developing his dynamics, but in 1948 those effects were not fully incorporated into his model. ${ }^{10}$ The second hypothesis, a less credible one, is that Prebisch used the example of a greater coefficient of imports in the centre than in periphery only as an expository device to facilitate the presentation of his theory. Still, when Prebisch dropped this assumption, he did not develop the opposite scenario in detail (i.e. the scenario in which the import coefficient is higher in the periphery than in the centre).

In accordance with the working of Prebisch's dynamics, the widening expenditure gap leads eventually to a greater redistribution of profits to the periphery and, hence, to an increase in incomes in the periphery and a narrowing of the gap. In other words, starting from a situation where the leakage coefficients are 0.50 and 0.20 , respectively, in the centre and the periphery, with increases of 100 and 20 units in income, as denoted by the respective lines, the widening gap would eventually begin to narrow as a result of the redistribution of profits, (leading to a shift from $\mathrm{C}$ to $\mathrm{D}$ in figure 3 ).

\footnotetext{
9 This text appears with the title "Progreso técnico y comercio internacional" [Technical Progress and International Trade] in Prebisch's collected works (Prebisch, 1948g, pp. 363-374). Nonetheless he was well aware of the import dependency of developing countries, as his analysis of the effects of the Great Depression demonstrates. Focusing on income effects after the Great Depression, he argued that imports increase because a considerable part of the direct consumption in a country, or the machinery and materials for its industries, comes from abroad, and the increase in income is reflected in higher levels of imports (Prebisch, 1991b).

10 See Mallorquín's interview with Ifigenia Martínez, who worked with Prebisch between 1949 and 1950. She mentions that when Prebisch visited Mexico in 1949 he was very much concerned with the external sector and the tendency towards disequilibrium in that sector as a country develops and changes its economic structure. She also maintains that the ECLAC development model, especially with regard to the external sector, was based on the Mexican experience (Mallorquín, 1998, p. 147).
}

Prebisch thought that this dynamic process would lead to greater profit and income expansion in the periphery than in the centre (Prebisch, 1993f). This, in conjunction with lesser leakage of periphery incomes to the centre (relative to the leakage from the centre to the periphery), would eventually more than offset the excess net demand in the centre, creating a situation of excess net supply. As final goods producers found themselves with a greater level of inventory than planned, they would reduce orders and demand, which would have a cascade effect in the chain of producers. Lower demand, prices and profits would cause a recession in the centre, and lower demand in the centre for products from the periphery would reduce profits and the level of activity in the periphery.

As Prebisch explains it:

"When there was excess net demand, business inventories declined and this led businessmen first to increase demand among themselves and then to increase production. And when there is insufficient net demand, unsalable inventories in the hands of businessmen increase, prompting them to reduce production. If we accept this relationship between variations in inventories and the behaviour of businessmen, it is inconceivable that businessmen will keep paying the factors of production in the centre and buying the same amounts in the periphery when unsold production is accumulating..." (Prebisch, 1993g, p. 469).

The relationship between inventories and demand is a crucial link in the transmission mechanism and a fundamental element of Prebisch's dynamics and of his arguments against "equilibrium economics." He explains this in the following way: "If we could completely eliminate the effect of inventories on demand, we would reach an equilibrium position. But this would mean suppressing the only means of action that a businessman has in a capitalist regime; it would mean eliminating one of the system's vital parts. As long as that vital part exists and the reactions of businessmen -not all of them- occur, the system will not reach the equilibrium." Inventory build-up (reduction) reflects, in turn, the importance of expectations as a determinant of decisions to expand (shrink) production. In the upturn, when as a result of increased demand, "...businessmen see a decline in inventories, not only do they seek to increase production in order to meet the new level of demand that they expect, but they also anticipate possible growth rates in accordance with the circumstances of the market... The same occurs in the downturn" (Prebisch, 1993g).

According to Prebisch, his theory was general and not confined to specific cases and assumptions. He therefore 
made three modifications to his model: he introduced fixed capital, allowed for an autonomous expansion of demand in the periphery via the creation of credit and considered the possibility of a higher import coefficient in the periphery than in the centre.

The use of both circulating and fixed capital goods in the production of final goods makes the production process longer than it would be if only circulating capital goods were used. In his model, Prebisch assumes that the creation of credit ("forced savings") finances the production of circulating capital and that "voluntary savings", in the form of funds hoarded during a period of contraction, finances investment in fixed capital goods. Hence, the introduction of investment in fixed capital into Prebisch's model adds an additional source of demand to that originating from investment in circulating capital. Incomes and profits paid in the course of producing fixed capital are added to those distributed in the process of producing circulating capital (Prebisch, 1993e). The additional source of demand, income and profits will be tempered by the amount of leakage to the periphery. As Prebisch puts it:

"Investments are also made by taking raw materials and articles in process from the periphery. Thus, only a part of the profits of the cyclical centre will become income for the factors of production in the centre; the other part will become payments for articles being produced in the periphery. In other words, when profits are used for fixed investment, a part of these profits will leak immediately to the periphery and that part will be subject to the rate of return in the periphery" (Prebisch, 1993h).

Prebisch assumes that total investment initially runs ahead of profits, until businessmen exhaust the savings used to finance capital goods. Thereafter, businesses only

\section{VIII}

\section{Conclusion}

The long process of development of Prebisch's economic ideas began in the 1920s and stretched into the late 1940s with his dynamic theory of economics. The essence of Prebisch's dynamic analysis, in which cycle and growth go hand in hand, is the introduction of the difference between the time required for incomes to circulate in the production process and the time required for final invest in circulating capital goods, using savings and the creation of credit to finance new investments, and profits exceed investment. The "excess profits" may either be consumed as final goods or be saved and reinvested to increase circulating capital. The more excess profits are saved and reinvested, the less businesses rely on credit creation. Since some profits are spent in the periphery, the demand for final goods slows down. Nonetheless, by the mechanism described above, the point of convergence between excess demand originating in the centre and the insufficiency of demand will eventually be reached. The introduction of fixed capital does not alter the basic premises of Prebisch's analysis; it simply introduces a detour in the path to the point of convergence.

The second modification introduced by Prebisch implies that the periphery does not play a passive role and does not depend completely on the centre's currency, but instead relies to some extent on its own increase in credit creation to finance its production activities. In this scenario, in contrast to that in which the periphery plays only a passive role, demand will be greater in both the centre and the periphery. However, Prebisch did not develop this hypothesis in detail. He considered it more of a curiosity than an hypothesis with practical applicability or one that reflected capitalist development (Prebisch, 1993i).

The final modification, in which the periphery has a higher import coefficient than the centre, simply shortens the time required to reach the point of convergence. Prebisch did not consider this an important assumption, even though it played a crucial role within the logic of The Economic Development of Latin America and its Principal Problems, which he published a few months after completing his last lecture on economic dynamics. production to be brought to and sold in the market. In that respect, he is part of a broad tradition of authors who sought to formalize macro-dynamics in the wake of the Keynesian revolution. Prebisch maintains elements that are Keynesian in spirit alongside others that are decidedly neoclassical, while at the same time introducing elements of the old classical school, as was to be expected in a 
period of transition in the economics profession. It was also to be expected of an author who was brought up in a rather intellectually eclectic environment.

Nevertheless, Prebisch stands alone among his contemporaries in seeking to explain the cyclical growth of the global economy as the result of the interaction between centre and periphery, in which the international division of labour matters. Not only does he explore the specificity of the problems of managing the peripheral economy, but he is unique among the economists who dealt with cyclical growth in addressing the importance of the shift in the global centre from the United Kingdom of Great Britain and Northern Ireland to the United States of America during the inter-war period.
His conception of the institutional and historical specificity of economic dynamics would eventually develop into what structuralists at ECLAC would refer to as the historical-structural method of analysis, which examined the process of structural transformation of developing economies from a historical perspective. Prebisch's understanding of capitalist dynamics, in the period just before he wrote his development manifesto and became Executive Secretary of ECLAC, was based on a theory that was intended to be general and allencompassing — going well beyond the problems of peripheral countries with declining terms of tradeand which became the hallmark of his contributions to economic analysis.

Bibliography

ECLAC (Economic Commission for Latin America and the Caribbean) (1951), Economic Survey of Latin America (E/CN.12/164/Rev.1), New York, United Nations.

Kalecki, M. (1971), Selected Essays on the Dynamics of the Capitalist Economy, 1933-1970, Cambridge, Cambridge University Press.

Keynes, J.M. (1936), The General Theory of Employment, Interest and Money, New York, Harcourt, Brace \& Co.

Mallorquín, C. (1998), Ideas e historia en torno al pensamiento económico latinoamericano, Mexico City, Plaza y Valdés.

Pérez Caldentey, E. and M. Vernengo (2011), "Portrait of the economist as a young man: Raúl Prebisch's evolving views on the business cycle and money, 1919-1949", CEPAL Review, No. 106 (LC/G.2518-P), Santiago, Economic Commission for Latin America and the Caribbean (ECLAC).

Prebisch, R. (2003a), "Introducción a la teoría dinámica de la economía”, Dr. Raúl Prebisch, 1901-1986: archivo de trabajo, J.F. Besa García (ed.), Santiago, Microfilmación y Sistemas Microsystem, S.A.

(2003b), "La teoría keynesiana y la realidad cíclica", $D r$. Raúl Prebisch, 1901-1986: archivo de trabajo, J.F. Besa García (ed.), Santiago, Microfilmación y Sistemas Microsystem, S.A. (2003c), "La crisis de la economía política y la revolución keynesiana", Dr. Raúl Prebisch, 1901-1986: archivo de trabajo, J.F. Besa García (ed.), Santiago, Microfilmación y Sistemas Microsystem, S.A.

(1993a), Raúl Prebisch: Obras, 1919-1949, vol. 4, M.

Fernández López (ed.), Buenos Aires, Raúl Prebisch Foundation. (1993b) "Teoría dinámica de la economía (I)", Raúl Prebisch: Obras, 1919-1948, vol. 4, Buenos Aires, Raúl Prebisch Foundation. (1993c), "Teoría dinámica de la economía (II)", Raúl Prebisch: Obras, 1919-1948, vol. 4, Buenos Aires, Raúl Prebisch Foundation. (1993d), "Teoría dinámica de la economía (III)", Raúl Prebisch: Obras, 1919-1948, vol. 4, Buenos Aires, Raúl Prebisch Foundation.

(1993e), "Teoría dinámica de la economía (IV)", Raúl Prebisch: Obras, 1919-1948, vol. 4, Buenos Aires, Raúl Prebisch Foundation.

(1993f), "Teoría dinámica de la economía (V)", Raúl Prebisch: Obras, 1919-1948, vol. 4, Buenos Aires, Raúl Prebisch Foundation. (1993g), "Teoría dinámica de la economía (VI)", Raúl Prebisch: Obras, 1919-1948, vol. 4, Buenos Aires, Raúl Prebisch Foundation. (1993h), "Teoría dinámica de la economía (VII)", Raúl Prebisch: Obras, 1919-1948, vol. 4, Buenos Aires, Raúl Prebisch Foundation.

(1993i), "Teoría dinámica de la economía (VIII)", Raúl Prebisch: Obras, 1919-1948, vol. 4, Buenos Aires, Raúl Prebisch Foundation.

(1993j), "Panorama general de los problemas de regulación monetaria y crediticia en el continente americano: América Latina", Raúl Prebisch: Obras, 1919-1948, vol. 4, Buenos Aires, Raúl Prebisch Foundation.

(1993k), "Los planes monetarios internacionales, la moneda y los ciclos económicos en la Argentina", Raúl Prebisch: Obras, 1919-1948, vol. 4, Buenos Aires, Raúl Prebisch Foundation.

(19931), "La experiencia monetaria argentina desde la crisis mundial y la creación y funcionamiento del banco central, la moneda y los ciclos económicos en la Argentina", Raúl Prebisch: Obras, 1919-1948, vol. 4, Buenos Aires, Raúl Prebisch Foundation.

(1991a), Raúl Prebisch: Obras, 1919-1948, vols. 1, 2 and 3, M. Fernández López (ed.), Buenos Aires, Raúl Prebisch Foundation. (1991b), "Tendencias del balance de pagos", Raúl Prebisch: Obras, 1919-1948, M. Fernández López (ed.), Buenos Aires,

Raúl Prebisch Foundation.

(1951a), "Interpretação do processo de desenvolvimiento econômico", Revista Brasilera de Economía, vol. 5, No. 1.

(1951b), "Growth, disequilibrium and disparities: interpretation of the process of economic development", Economic Survey of Latin America (E/CN.12/164/Rev.1), New York, United Nations. (1950), The Economic Development of Latin America and its Principal Problems (E/CN.12/89), Santiago, Economic Commission for Latin America and the Caribbean (ECLAC).

(1948a), "Introducción al curso de dinámica económica", Revista de la Facultad de Ciencias Económicas, vol. 1, No. 4, Buenos Aires, University of Buenos Aires.

(1948b), "La tasa de interés en las doctrinas clásica y keynesiana", Apuntes de Economía Política, Buenos Aires.

(1948c), "La tasa de interés como reguladora del sistema económico", Apuntes de Economía Política, vol. 4, Buenos Aires.

(1948d), "Los tres planos independientes de la teoría clásica", Apuntes de Economía Política, Buenos Aires.

(1948e), "Papel del beneficio en la realidad capitalista", Apuntes de Economía Política, Buenos Aires. 
(1948f), "Cotejo entre el esquema clásico y la realidad cíclica", Apuntes de Economía Política, Buenos Aires.

(1948g), "Progreso técnico y comercio internacional", Apuntes de Economía Política, Buenos Aires.

(1948h), Apuntes de Economía Política, Buenos Aires.

(1947a), Introducción a Keynes, Buenos Aires, Fondo de Cultura Económica.

(1947b), "Programa de economía política (dinámica económica)", Buenos Aires, University of Buenos Aires.
(1984), "Five stages in my thinking on development", Pioneers in Development, G. Meier and D. Seers (eds.), Oxford University Press. (1981), Capitalismo periférico: crisis y transformación, Mexico City, Fondo de Cultura Económica.

Schumpeter, J. (1946), “John Maynard Keynes 1883-1946”, American Economic Review, vol. 36, No. 4, Nashville, Tennessee, American Economic Association.

Termini, V.A. (1981), "Logical, mechanical and historical time in economics",Economic Notes, vol. 10, No. 3, Monte dei Paschi di Siena. 